\title{
Gwilym Jones. Shakespeare's Storms. Manchester: Manchester University Press, 2015. Pp xi, 198.
}

\author{
EDWARD J. GEISWEIDT
}

University of New Haven

Ecocritics might well have preconceived notions about a book titled Shakespeare's Storms, the winner of the 2016 Shakespeare's Globe Book Award. Its author, Gwilym Jones, seems to have preconceptions of ecocritics' preconceptions, making for some tricky moments in an otherwise deservedly lauded contribution to Shakespearean scholarship. Jones's familiarity with weather references in the canon is wide-ranging, but his chapter-length readings of five plays (Julius Caesar, King Lear, Macbeth, Pericles, and The Tempest) are sharply focused. The full chapter readings (save the last) are preceded by mini-chapters (ranging from three to nine pages) in which Jones usefully provides historical research on early modern meteorology.

Jones offers a narrative of development in Shakespeare's dramatic representations of storms, proposing that throughout Shakespeare's career, 'we see an increasing interest in bringing the storm into a more immediate, and thereby dramatic and threatening, presentation' (3). The book's argument centres on spectatorship of the storms (whether by characters in the plays, or, more to Jones's point, audiences in the theatre) and interpretations of their origins - natural or supernatural. One of Jones's main contentions is that the characteristically natural origins of Shakespeare's storms set them apart from the typically supernatural storms in works by contemporary playwrights, and, furthermore, that Shakespeare's audiences came to expect that the Shakespearean storms they witnessed in the theatre could be explained without recourse to the supernatural. For all this emphasis on the natural, one might expect Jones to have an easy relationship with ecocritics. Such does not seem to be the case.

In his introduction, Jones begins the subsection 'Shakespeare's Storms and Ecocriticism' by declaring, 'I think I have already failed the test' (19), the test being the titular question posed by Sharon O'Dair's chapter in Ecocritical Shakespeare: 'Is It Shakespearean Ecocriticism If It Isn't Presentist?. ' Jones points to his historicist approach as the source of his supposed failure, and he retorts with an oddly preemptive defense: 'I suspect that I may be accused of coding "presentist ... as unscholarly" and will be eyed warily by self-proclaimed ecocritics as a result' (19; quoting O'Dair, 75). From the Scylla of O'Dair's presentism, Jones steers toward the Charybdis of Simon Estok's activism: 'There is little in the 
way of advocacy or activism to be found in my argument, and so I also fall foul of Simon C. Estok's criteria for "Doing Ecocriticism with Shakespeare" (20). ${ }^{2}$ Unfortunately, Jones seems to have been goaded by Estok's scolding of 'legions of staid thematicists who muse endlessly as the world smolders to an end'. 3 Jones offers the salient response that ' $\mathrm{t}$ ] hematic studies can teach us not only what to look at, but also how to look at ourselves looking' (21), a claim he supports throughout the book, particularly in his chapter on The Tempest. But Jones also makes a somewhat baffling claim: 'that our experience of real weather is fundamentally aesthetisced [sic] by dramatic weather prompts us to remember that activism is about changing minds, not actions' (21). Jones 'prompts us to remember' an idea not subject to recall; I doubt many of his readers, ecocritics and thematicists alike, actually believe that activism is not about changing actions.

I do not mean for polemics to overshadow my assessment of Jones's smartly crafted book. I will return to his contributions to ecocriticism later, but first I want to highlight a few of the remarkable insights and readings that scholars would miss were they to dismiss Shakespeare's Storms for failing a litmus test. In chapter two, Jones argues that Julius Caesar — the play containing 'Shakespeare's first staged storm' (31) — provided the playwright a vehicle for spectacle made possible by the new Globe Theatre. He describes the 'thunder runs' that simulated thunder, and the fireworks, squibs, and swevels that created stage lightning. Jones imagines that such special effects were used on a grand scale in the 1599 production largely to announce the Globe's arrival on the South Bank. Jones concludes the chapter with a point that the Julius Caesar storm does not signify the supernatural but is, instead, 'linked to human violence' (49), a correlation for which Jones prepares his readers in the preceding mini-chapter, 'Thunder'.

In 'King Lear: Storm and the Event', Jones demonstrates his impressive talents as a close reader of early modern drama. Starting with Albany's simple comment, 'Well, well, th'event' (1.4.344), Jones explores 'the ways in which King Lear is dominated by the event' (59). His premise is that the event (the storm, of course) does not happen 'in a particular place' but is 'characterised by an absence of location' (59). Thus, Jones questions the popular (and critical) assumption that 'the heath' causes Lear's transformation (62; emphasis in original). In other words, the heath steals the thunder from the storm, which is the real catalyst for Lear's change. Citing critical precedent, Jones banishes the heath so that critics of Lear can 'process' a pre-Restoration understanding of the play (62). Jones has a way of deploying moments from throughout the canon in support of his larger readings. For instance, to prove that Shakespeare's language can be quite evocative of place when the playwright desires, Jones offers a concise but effective reading of the 
'pinching cave' in Cymbeline (3.3.38). The implication is that, if Shakespeare had wanted his audience to imagine a heath, there would be no room for debating the existence of the heath today.

'Macbeth: Supernatural Storms, Equivocal Earthquakes' is the book's weakest chapter, with signposting that belabours a relatively simple claim about the distinction between natural and supernatural causes of storms in the play. The discussion of earthquakes (also part of early modern meteorology) breaks the monotony of the chapter (and subtly ties it to the previous chapter, 'Wind'). More consideration of how Middleton's adaptation of the text may have influenced the depiction of storms would have helped to bring this chapter to the level of the book's next reading, 'Pericles: Storm and scripture', in which Jones cleverly draws contrasts between the co-authors' (Shakespeare and George Wilkins) distinctive dramatizations of weather. Pericles is significant in Shakespeare's career because it marks the point at which he moves from diegetic to mimetic representation of a specific kind of storm - the sea-storm. Jones locates the differences between Shakespeare's and Wilkins's sea-storms in their respective Biblical influences: Luke and Jonah for the former, 2 Maccabees and 2 Kings for the latter. The chapter's emphasis on how Shakespeare depicts sea-storms sets Jones up for his complex reading of the titular event in The Tempest.

In chapter nine, 'The Tempest and Theatrical Reality', Jones takes a confidently ecocritical stance without anxiety over how other ecocritics might regard him, and the result is spectacular. Jones adopts Timothy Morton's concept of rendering $^{4}$ to show how the text of The Tempest presents a storm that is 'as close to a real one as possible' (127). Special effects, limited in the Blackfriars Theatre, and the sailors' precise nautical language contribute to the rendering. Miranda's revelation of Prospero as the tempest's originator induces the audience (trained, as Jones contends, to expect natural weather) to reconsider their interpretation of the storm. With the sea-storm's theatrical rendering revealed, the nature (or supernature) of subsequent weather events in the play also becomes a question of theatricality. Echoes of ecocritics Robert N. Watson and Morton can be heard in the conclusion Jones draws regarding the theatricality of the play's weather: ' $[\mathrm{H}]$ umankind can only represent nature as theatre, for to represent it through theatre is to mistakenly conclude that it is possible to know nature objectively' (147). One of the most fascinating parts of this chapter is Jones's reading of Ariel, whom he cleverly dubs 'the I of the storm' (140). Ariel is depicted 'both as a slave and as a personification of weather', demonstrating that 'the fantasy of new world domination is necessarily also a fantasy of domination over nature' (146). 
Shakespeare's Storms is a remarkably well-plotted book, and after an exciting ninth chapter, an ecocritic might arrive at the three-page 'Conclusion' hoping at last for a glancing reference to weather events of, say, 2004, 2005, or 2015. One finds, however, an anecdote about a 1505 thunderstorm that frightened a young Martin Luther. Moving work has been done on Shakespeareans' engagement with a real storm; it would have been fitting to see Jones converse with some of the essays in a special issue of Borrowers and Lenders titled 'Shakespeareans in the Tempest: Lives and Afterlives of Katrina', edited by O'Dair. ${ }^{5}$ But Jones remains firm in his refusal of presentism. What he offers instead is a promising model for a performance-oriented approach to Shakespearean ecocriticism.

\section{Notes}

1 Sharon O'Dair, 'Is It Shakespearean Ecocriticism If It Isn't Presentist?', Lynne Bruckner and Dan Brayton (eds), Ecocritical Shakespeare (Burlington, VT, 2011), 70-85.

2 See the first chapter of Simon C. Estok, Ecocriticism and Shakespeare: Reading Ecophobia (New York, 2011), 1-17, http://dx.doi.org/10.1057/9780230118744.

3 Simon C. Estok, 'Afterword: Ecocriticism on the Lip of a Lion', Bruckner and Brayton, 239-46; 240.

4 Timothy Morton, Ecology without Nature: Rethinking Environmental Aesthetics (Cambridge, MA, 2007), 35-6.

5 Sharon O'Dair (ed.), 'Shakespeareans in the Tempest: Lives and Afterlives of Katrina', Borrowers and Lenders 5.2 (2010). 